\title{
ON THE STUDY OF THE INFLUENCE OF EXTERNAL PRESSURE AND CARBON ON THE STRUCTURE FORMATION AND PROPERTIES OF COMPACTS BAKED ON THE BASIS OF RAPIDLY COOLED Nd-Fe-(C,B)-Cu-Ti ALLOYS (PART 2)
}

\begin{abstract}
Objective. Complex study of thermodynamic and physico-chemical conditions of phase formation in ready permanent magnets, manufactured on the basis of Fe-Nd-B systems.

Research methods: metallographic, $x$-ray, magnetometric.

Result. The influence of external pressure and a small amount of carbon $(0.17 \ldots 0.86 \% \mathrm{AO})$ on the structure and properties of permanent magnets made on the basis of the $\mathrm{Nd}-\mathrm{Fe}-\mathrm{B}$ system doped with copper and titanium. For the manufacture of permanent magnets with high magnetic energy, fast cooling products from the liquid state are used. To do this, the flakes obtained by the LRE method were pressed in a mold and spiked in a vacuum. The mold and bolts that fasten are made of alloys that have different coefficients of linear expansion. This method allows to achieve high pressure $(\approx 1 \mathrm{HPa})$ during sintering. Sintering was performed in a vacuum under pressure $P=12 \mathrm{MPa}$ and at a temperature of $1013 \mathrm{~K}$.
\end{abstract}

It is shown that carbon has a dual effect on the properties of alloys $N d_{15,2} F_{7_{75,5-x}} C_{x} B_{6,6} C u_{1,57} T i_{1,38^{\circ}}(x: 0.33 \ldots 0.86 \%$ of the stock.): on the one hand, in the presence of carbon (0.33...0.86 at.\%) in the liquid alloy, micro-areas are formed, which are enriched with copper, on the basis of which, when quenched from the liquid state, ndcu 2 crystals are born. On the other hand, during crystallization of the amorphous component in alloys $\mathrm{Nd}_{15,2} \mathrm{Fe}_{75,5-\mathrm{x}-\mathrm{C}} \mathrm{C}_{x} \mathrm{~B}_{6,6} \mathrm{Cu}_{1,57} \mathrm{Ti} i_{1,38}$ under high pressure conditions, imperfections are formed in which the alloying elements - carbon, copper, titanium, neodymium-are diffused. Micro-areas, reaching critical sizes, become an obstacle to the displacement of domain boundaries. And in the first, and in the second cases actively manifests itself pinning-effect.

Scientific novelty. It is found that the sintering temperature of rapidly cooled alloy flakes decreases $N d_{15,2} F_{35,5-x} C_{x} B_{6,6} C u_{1,57} T i_{1,38}$ in conditions of high pressure of about 0.9 GPA from the technological $1323 \mathrm{~K}$ to the temperature of $1013 \mathrm{~K}$ practically does not affect the rate of nucleation of metastable phases $\mathrm{NdCu}$ and $\mathrm{Nd}_{2} \mathrm{Fe}_{14} \mathrm{~B}$ and at the same time reduces the speed of their growth. However, this leads to an increase in the coercive force of the finished magnets from $160 \mathrm{kA} / \mathrm{m}$ to $1300 \mathrm{kA} / \mathrm{m}$.

Practical significance. The results obtained in this work are important for the further development of physical material science of magnetically hard materials and modern technology.

Key words: sintering " heat" pressure, annealing, the main hard magnetic phase, the phase with reduced metastability, the coercive force.

\section{Introduction}

Today magnetic materials are used in all spheres of life. Permanent magnets are an integral part of various spheres of human life, so improving its magnetic characteristics such as residual induction and coercive force is an important and priority task. As is known, the coercive force of magnets can be increased both by changing the microstructure and phase composition of the magnet material (the structural constant $\mathrm{C}$ ), and by changing the fundamental characteristics of the magnetojorst phases (saturation magnetization $\mathrm{J}_{\mathrm{s}}$, magnetocrystalline anisotropy field $\mathrm{H}_{\mathrm{a}}$ ). however, in the manufacture of permanent magnets, the size of the main fraction of the powders should not exceed $10 \ldots 20 \mu \mathrm{m}$, after sintering, the particles should be isolated from each other by a non-ferromagnetic layer to suppress the nucleation of the reverse magnetization domains. There are several ways to solve this problem:

1) modification of main hard magnetic phase $\mathrm{Nd}_{2} \mathrm{Fe}_{14} \mathrm{~B}$ 3a special introduction to the fusion of elements of a certain concentration;

2) quenching from the liquid state of the initial alloys;

3) HDDR method.

\section{The analysis of literary sources}

In 1984, Herbst [1] determined the structure of the compound by $\mathrm{x}$-ray diffraction and neutron diffraction $\mathrm{Nd}_{2} \mathrm{Fe}_{14} \mathrm{~B}$. Connection $\mathrm{Nd}_{2} \mathrm{Fe}_{14} \mathrm{~B}$ it has a tetragonal crystal lattice and belongs to the space group $P 4_{2} / \mathrm{mnm}$. It consists of 68 atoms in an elementary cell, has six crystallographic positions of iron and two positions of neodymium (Fig. 1). For the analysis of the Mossbauer spectra of the phase $\mathrm{Nd}_{2} \mathrm{Fe}_{14} \mathrm{~B}$ [1] the Wigner-Seitz cell method was used and 
the number of nearest neighboring atoms for different crystallographic positions of iron atoms was determined: $8 j_{1}, 8 j_{2}, 16 k_{1}, 16 k_{2}, 4 e, 4 c$. Nodes $8 j_{1}$ and $8 j_{2}$ it has 12 nearest neighboring iron atoms, nodes $I 6 k_{1}$ and $16 k_{2}$ have 10 nearest neighbors, node $I 6 k_{1}$ it has 1 boron atom instead of iron as the nearest neighboring atom. Nodes $4 e$ and $4 c$ respectively, 9 and 8 of the nearest neighboring iron atoms. Lattice parameters: $c=1.22 \mathrm{~nm}$ and $a=0.881 \mathrm{~nm}$. This structure provides a uniaxial magnetic anisotropy of the compound $\mathrm{Nd}_{2} \mathrm{Fe}_{14} \mathrm{~B}$. In the center of the trigonal prism formed by three iron atoms, there is a boron atom. Fundamental magnetic characteristics of the phase $\mathrm{Nd}_{2} \mathrm{Fe}_{14} \mathrm{~B}$ there is a field of magneto-crystalline anisotropy $H_{a}=5,4 \mathrm{MA} / \mathrm{m}$, saturation magnetization $J_{s}=1,6 \mathrm{~T}$, Curie temperature $T_{k}=585 \mathrm{~K}$, residual induction $B_{r}=1,2 \mathrm{TL}$ [2-4]. Magnetic properties of the phase $\mathrm{Nd}_{2} \mathrm{Fe}_{14} \mathrm{~B}(\mathrm{C})$ determines the exchange interaction between the iron atoms in the iron sublattice, and the optimal distance between the atoms forms the neodymium sublattice (or other heavy REM) due to its size.

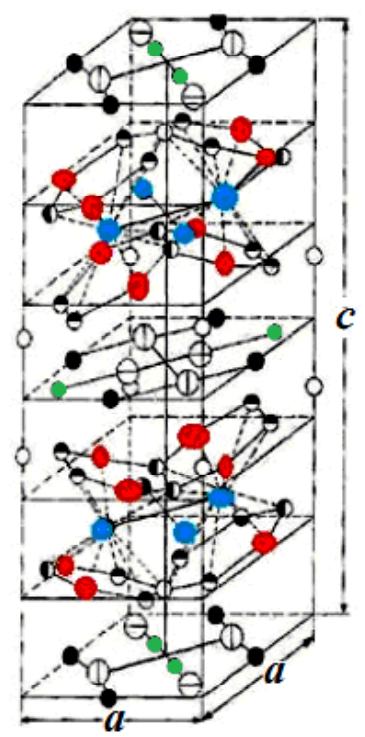

$$
\begin{aligned}
& \Theta N d_{1}, 4 f \\
& \text { (1) } \mathrm{Nd}_{2}, 4 \mathrm{~g} \\
& \text { - } \mathrm{Fe}_{1}, 4 \mathrm{e} \\
& \text { - } \mathrm{Fe}_{2}, 4 \mathrm{c} \\
& \text { - } F e_{3}, 8 j_{1} \\
& \text { - } \mathrm{Fe}_{4}, 8 \boldsymbol{j}_{2} \\
& \text { - } \mathrm{Fe}_{5}, 16 \mathrm{k}_{1} \\
& \text { - } \mathrm{Fe}_{6,}, 16 \mathrm{k}_{2} \\
& \text { - } B(C), 4 f
\end{aligned}
$$

Fig. 1. Phase unit cell $\mathrm{Nd}_{2} \mathrm{Fe}_{14} \mathrm{~B}(\mathrm{C})$ [6]

Introduction to the alloy for the manufacture of sintered magnets based on type compounds $\mathrm{R}_{2} \mathrm{~T}_{14} \mathrm{X}$ some elements in a certain concentration can be an effective way to solve the problem of optimizing the phase composition and microstructure of the magnet material, changing the fundamental characteristics of the magneto-porous phases. In addition, the introduction of such additives increases mechanical strength, corrosion resistance, solves the problems of improving the manufacturability of the material (improving the conditions of melting and crystallization of ingots) [7].

Nd-Fe-B Materials use two mechanisms to explain the nature of the highly coercive state:

- delay in the formation of reverse magnetic phase embryos [8, 9];

- delay of the displacement of domain walls $[1,10]$.
However, these mechanisms do not allow to fully interpret the entire range of experimental data [5, 11-14]. A comprehensive analysis was carried out in $[9,10]$, which showed that in the case of the application of the model of the viscocoercitive state, the greatest correspondence between the theoretical representations and the experimental results obtained at room temperature is obtained. This model is based on the mechanism of delay of formation of reverse magnetization embryos. The authors attribute the discrepancy between the calculated and experimental data to the presence of grains in the samples, which are oriented differently. At temperatures above 423 $\mathrm{K}$ is dominated by the delay mechanism of the displacement of domain walls with magnetic inhomogeneities of grain boundaries [15-18]. The authors in these works suggest that there is a ferromagnetic phase with a close Curie temperature and low coercive force in the Micrograin layers, but this phase could not be detected experimentally [19].

All alloying elements can be divided into three large groups:

1 - the Introduction of terbium, dispersion, gadolinium into the neodymium sublattice can be an effective method of increasing the magnetic properties of finished products;

2 - the replacement of iron atoms into the cobalt (raises the Curie temperature), Nickel (contributes to thermal stability), aluminum, niobium, manganese, molybdenum.

The difficulty lies in the fact that the iron atoms in the elementary cell of the phase $\mathrm{Nd}_{2} \mathrm{Fe}_{14} \mathrm{~B}$ they occupy six non-equivalent crystallographic positions [20], so it is almost impossible to predict in which positions the doping element will be replaced and whether such replacement will occur at all;

3 - the introduction of surface-active elements, copper, titanium, molybdenum, aluminum, gallium, on the basis of which are formed of non-magnetic phase to isolate the magnetic grains of the hard phase $\mathrm{Nd}_{2} \mathrm{Fe}_{14} \mathrm{~B}(\mathrm{C})$ and increase its corrosion resistance.

In alloys with iron crystal structure isomorphic to the structure of the compound $\mathrm{Nd}_{2} \mathrm{Fe}_{14} \mathrm{~B}$, is formed with most of REE from $\mathrm{La}$ to $\mathrm{Lu}$ (except for $\mathrm{Eu}$ ). In the compounds $\mathrm{R}_{2} \mathrm{Fe}_{14} \mathrm{~B}$ large values of coercive force are possible in the interaction of boundaries with defects:

- the energy density of the boundary is high, so large changes are possible;

- the thickness of the domain boundary had, therefore, these changes in the energy of the boundaries can take place at a small displacement, which will lead to a high value of the energy gradient and the corresponding values ${ }_{\mathrm{I}} \mathrm{Hc}$.

In [21], the authors studied sintered magnets, cast and quickly hardened alloys of composition (in weight. \%) $\mathrm{Nd}_{35} \mathrm{Co}_{5} \mathrm{~B}_{1,15} \mathrm{Al}(\mathrm{Ti})_{1,15} \mathrm{Fe}_{57,7}$ for the behavior of alloying elements ( $\mathrm{Co}, \mathrm{Al}, \mathrm{Ti})$ when introduced into the stoichiometric compound $\mathrm{Nd}_{2} \mathrm{Fe}_{14} \mathrm{~B}$. Analysis and comparison of mussbauer spectra showed that for these materials quadrupole splitting, isomeric shifts, the values of effective fields within the experimental error are 
determined by the chemical composition of the samples and do not depend on their state.

It has also been shown that in nodes $16 \mathrm{k}_{2}$-like cobalt atoms can replace iron atoms. In the crystal lattice $\mathrm{Nd}_{2} \mathrm{Fe}_{14} \mathrm{~B}$ the distance between the atoms $\mathrm{Fe}\left(\mathrm{k}_{2}\right)-\mathrm{Fe}\left(\mathrm{j}_{1}\right)$ the smallest, and it increases the possibility anti feromagnetic exchange interaction between the magnetic moments of the atoms [22]. The introduction of cobalt atoms reduces the number of negative $\mathrm{Fe}\left(\mathrm{k}_{2}\right)-\mathrm{Fe}\left(\mathrm{j}_{1}\right)$ exchange bonds, which leads to an increase in Curie temperature and saturation magnetization [23].

Despite the fact that the addition of cobalt significantly increases the Curie temperature, its use should be in a certain amount - an increase in the concentration of co Contributes to a decrease in the coercive force of sintered nd-Fe-B magnets [24]. In [23], the authors explain this fact by the formation of new soft magnetic phases based on cobalt, which worsens the magnetic isolation of the phase grains $\mathrm{Nd}_{2} \mathrm{Fe}_{14} \mathrm{~B}$.

$\mathrm{Al}$ atoms replace $\mathrm{Fe}$ atoms in positions $8 \mathrm{j}_{2}$ and $16 \mathrm{k}_{2}$ type's. In these positions $\mathrm{Fe}$ atoms have a magnetocrystalline anisotropy of plane type [21]. It is possible that the introduction of non-magnetic aluminum atoms leads to an increase in the resulting uniaxial magnetocrystalline anisotropy of the phase $\mathrm{Nd}_{2} \mathrm{Fe}_{14} \mathrm{~B}$.

Analysis of hyperfine scattering fields of mцssbauer spectra in samples with addition of titanium and without titanium found no significant difference, that is, titanium atoms are not included in the crystal lattice of the phase $\mathrm{Nd}_{2} \mathrm{Fe}_{14} \mathrm{~B}$. Perhaps part of the titanium goes to the formation of the non-magnetic phase $\mathrm{TiB}_{2}$, which prevents the movement of the domain walls. Also, titanium atoms are dissolved in the boundary phase, which is enriched with neodymium, than change its wetting ability. The above mentioned facts leads to an increase in the coercive force by almost 2 times (from $460 \mathrm{kA} / \mathrm{m}$ to $850 \mathrm{kA} / \mathrm{m})$.

A detailed study of the distribution of alloying additives in the nd-Fe-B material was carried out by mцssbauer spectroscopy [25].

In this paper, the authors compared the values of effective magnetic fields $\mathrm{H}_{\text {eff }}$ In this paper, the authors compared the values of effective magnetic fields $\mathrm{Nd}_{2} \mathrm{Fe}_{14} \mathrm{~B}$ for rafting $\mathrm{Nd}_{16,0} \mathrm{Fe}_{\text {bal }} \mathrm{Ti}_{1,26} \mathrm{Al}_{0,32} \mathrm{~B}_{7,2}$ та $\mathrm{Nd}_{16,0} \mathrm{Fe}_{\text {bal }} \mathrm{Ti}_{1,26} \mathrm{Al}_{0,32} \mathrm{~B}_{7,2}+0.5$ at. $\% \mathrm{M}$, where $\mathrm{M}$ is a specially introduced metal.

Thirteen metals were used for research, which are divided into four groups:

- group $\mathrm{A}: \mathrm{Cu}, \mathrm{Ga}, \mathrm{Al}$ - metals with unfinished outer electron shell;

- group B: Hf, Ti, V, Mo, Nb, Cr-transition metals with unfinished $3 d$ shell; the number of electrons on the unfinished shell is less than in the iron atom;

- group $\mathrm{C}$ : $\mathrm{Co}, \mathrm{Ni}$ - transition metals with unfinished $4 \mathrm{~d}$ shell; the number of electrons on the unfinished shell is greater than in the iron atom;

- group D: Tb, Dy is a heavy rare-earth metals.
Analysis of the data table. 1 showed that in the crystal lattice $\mathrm{Nd}_{2} \mathrm{Fe}_{14} \mathrm{~B}$ iron atoms can replace metals from groups A, B, C. an Increase in the number of $3 \mathrm{~d}$ electrons helps to reduce $\mathrm{H}_{\text {eff }}$ (elements from groups $\mathrm{b}$ and $\mathrm{C}$ ). With the introduction of atoms of rare earth metals ( $\mathrm{Tb}, \mathrm{Dy})$, replacing the neodymium and value $\mathrm{H}_{\text {eff }}$ increases by the same amount in all positions of the iron, but the position of $4_{e}$. The authors [26] believe that similarly behave and other rare earth metals.

Thus, one of the effective methods of improving the fundamental magnetic characteristics of nd-Fe-B-Based magnets is the grinding and modification of the main magneto-rigid phase $\mathrm{Nd}_{2} \mathrm{Fe}_{14} \mathrm{~B}$ due to the special introduction of elements of a certain concentration into the alloy and quenching from the liquid state of the initial alloys.

Currently, the promising ways to improve the magnetic characteristics is the addition of terbium, dysprosia and gadolinium, and the addition of cobalt contributes to an increase in Curie temperature and residual magnetization. The introduction of low-melting mixtures of rare-earth metals, non-magnetic metals (aluminum, titanium, copper, gallium) contributes to the creation of a thin insulating film on the basis of phases with these elements around the ferromagnetic grains $\mathrm{Nd}_{2} \mathrm{Fe}_{14} \mathrm{~B}$. However, more research is needed to determine the optimal ratio between the leguvalnymi elements to achieve the greatest magnetic, temperature and corrosion characteristics of sintered magnets based on the system Nd-Fe-B.

\section{Mathematical modeling vlive sizes of domains of the phase $\mathrm{nD}_{2} \mathrm{fE}_{14}$ B and non-magnetic impurities in the $\mathrm{H}_{\mathrm{C}}$ systems nD-fE-B}

At the first stage, we find out how the size of the inclusions and the distance between them affect the values of the coercive force and the velocity of the domain boundaries of permanent magnets. According to the theory of Kondorsky [27-30], the smaller the size of the inclusions and the thicker they are, the lower the speed of the domain boundaries and, accordingly, the more important the coercive force becomes.

For the Nd-Fe-B System, the values of the magnetic characteristics and the width of the domain wall are shown in table. 1 [28-30]. According to the theory of inclusions [27, 29, 30], the domain boundary in the initial state tries to overturn the maximum possible number of non-magnetic inclusions. This reduces its surface energy. Let the inclusions have the shape of a sphere with diameter $d$ and are located in a cubic crystal with constant S(Fig. 1).

Let the coercive force be found by the following formula:

$$
H_{c}=\frac{1}{I_{s}} \cdot\left(\frac{\partial \sigma}{\partial x}\right)_{\max } .
$$


Table 1 - Magnetic characteristics for Nd-Fe-b system

\begin{tabular}{|c|c|c|c|c|}
\hline $\begin{array}{l}\text { Became exchange } \\
\text { interaction } A\end{array}$ & Became anisotropy, $K$ & Magnetic saturation $I s$ & $\gamma_{\text {гр }}$ & $\begin{array}{c}\text { The width of the domain } \\
\text { wall } \delta, \mathrm{nm}\end{array}$ \\
\hline $1,25 * 10^{-11} \mathrm{~J} / \mathrm{m}$ & $4,5^{*} 10^{6} \mathrm{~J} / \mathrm{m}^{3}$ & $\begin{array}{c}1,61 * 10^{6} \mathrm{~A} / \mathrm{m} \\
1,61 \mathrm{~T}\end{array}$ & $0,03 \mathrm{~J} / \mathrm{m}^{2}$ & \multirow[t]{2}{*}{5,24} \\
\hline $1,25 * 10^{-6} \mathrm{erg} / \mathrm{cm}$ & $4,5^{*} 10^{7} \mathrm{erg} / \mathrm{cm}^{3}$ & $1,61 * 10^{4} \mathrm{G}$ & $26,94 \mathrm{erg} / \mathrm{cm}^{2}$ & \\
\hline
\end{tabular}

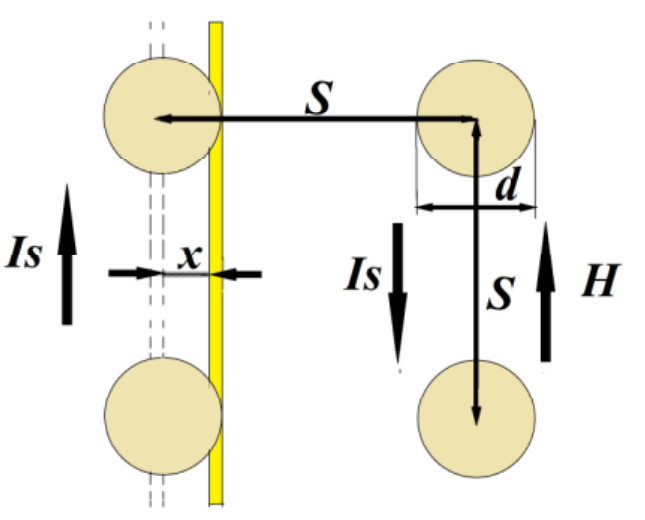

Fig. 2. The movement of the domain limit under the influence of an external magnetic field $n$

The density of the surface energy is as follows:

$$
\sigma(x)=\sigma_{0} \cdot \frac{S^{2}-\pi\left(\frac{d^{2}}{4}-x^{2}\right) S^{2}-\pi\left(\frac{d^{2}}{4}-x^{2}\right)}{S^{2}},
$$

anywhere $\sigma_{0}$ - the average density of the surface energy of the boundary.

After differentiating the expression (2) and substituting it into the expression (1), we obtain a formula for determining the coercive force for the inclusion model:

$$
H_{c}=\frac{\pi}{2} \cdot \frac{\sigma_{0}}{I_{0}} \cdot \frac{d}{S^{2}}
$$

or:

$$
H_{c}=\left(\frac{\pi}{6}\right)^{2 / 3} \cdot \frac{K \cdot \delta}{I_{s}} \cdot \frac{d}{S^{2}},
$$

where $I_{s}$ - magnetic saturation, K-became anisotropy;

$\delta$ - the width of the domain boundary for phase $\mathrm{Nd}_{2} \mathrm{Fe}_{14} \mathrm{~B}$

$S$ - distance between inclusions, $\mathrm{d}$ is the size of the inclusion.

Formula 4 was used for modeling. The calculation results are shown in Fig. 3. From Fig. 3 it can be seen that by reducing the size of non-magnetic inclusions to $5 \ldots 10$ $\mathrm{nm}$, which is commensurate with the width of the domain boundary for the phase $\mathrm{Fe}_{14} \mathrm{Nd}_{2} \mathrm{~B}$, there is a sharp increase in the values of the coercive force to $5 \mathrm{MA} / \mathrm{m}$.

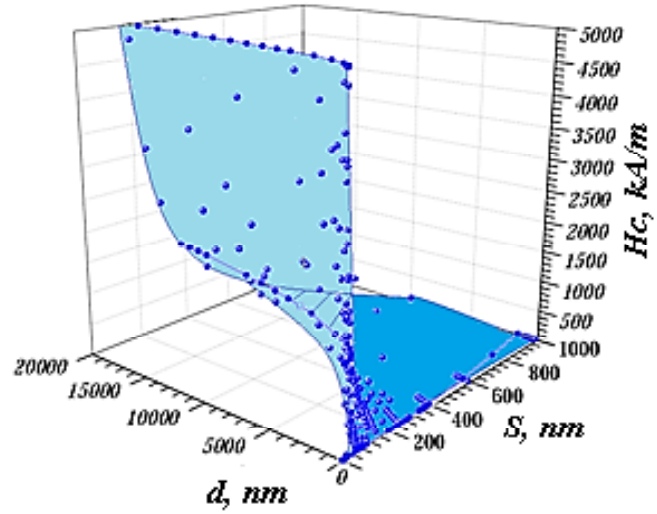

Fig. 3. Dependence of the coercive force of the phase $\mathrm{Nd}_{2} \mathrm{Fe}_{14} \mathrm{~B}$ from the size of non-magnetic phase inclusions $\mathrm{NdCu}_{2}$ and the distance between them

\section{Materials and methods studies}

As starting materials for producing sintered compacts of high-energy used quickly hardened tape. Rapidly quenched ribbon was produced by the method of melt spinning is presented to the vacuum setting rapid hardening "Tape-3" (NSC "KIPT", Kharkiv). The chemical composition of the alloys obtained in the work is shown in table. 2 .

Table 2 - Chemical composition of the initial alloys of the system Nd-Fe-(B,C)-Cu-Ti

\begin{tabular}{|c|c|c|c|c|c|c|}
\hline \multirow{2}{*}{$\begin{array}{c}\text { № } \\
\text { sample's }\end{array}$} & \multicolumn{7}{|c|}{ Chemical composition, \% at. } \\
\cline { 2 - 7 } & $\mathrm{Nd}$ & $\mathrm{Fe}$ & $\mathrm{C}$ & $\mathrm{B}$ & $\mathrm{Cu}$ & $\mathrm{Ti}$ \\
\hline 1 & 15,2 & 75,33 & 0,17 & 6,5 & 1,57 & 1,38 \\
\hline 2 & 15,2 & 75,17 & 0,33 & 6,5 & 1,57 & 1,38 \\
\hline 3 & 15,2 & 75,08 & 0,42 & 6,5 & 1,57 & 1,38 \\
\hline 4 & 15,2 & 74,99 & 0,51 & 6,5 & 1,57 & 1,38 \\
\hline 5 & 15,2 & 74,14 & 0,86 & 6,5 & 1,57 & 1,38 \\
\hline
\end{tabular}


Sintering was carried out for the alloy $\mathrm{Nd}_{15,2}$ $\mathrm{Fe}_{75,5-\mathrm{x}} \mathrm{C}_{\mathrm{x}} \mathrm{B}_{6,5} \mathrm{Cu}_{1,5} \mathrm{Ti}_{1,3}$ (x: $0.17 \ldots 0.86 \%$ at.) after compaction under a mechanical press at the initial pressure $\mathrm{P}=12 \mathrm{MPa}$ (total pressure was $0.9 \mathrm{GPa}+\mathrm{P}_{\mathrm{i}} \mathrm{MPa}$ ) [31]. Sintering occurred at a temperature $\mathrm{T}=1013 \mathrm{~K}\left(740^{\circ} \mathrm{C}\right)[32]$ for $1.5 \mathrm{~h}$, the Choice of this sintering temperature was due to the fact that at a temperature of $928 \mathrm{~K}$ a triple fusible eutectic is formed $\mathrm{Fe}_{14} \mathrm{Nd}_{2} \mathrm{~B}+\mathrm{Nd}_{11} \mathrm{Fe}_{4} \mathrm{~B}_{4}+\mathrm{Nd}$, which promotes liquid-phase sintering.

The reliability of the scientific results is confirmed by the use of modern research instruments (optical microscope OLIMPYS IX-70, Dron-3 diffractometer, scanning electron microscope JEOL JSM-6360LA, vibration magnetometer, closed-loop magnetometer); the error in the reproduction of the results is $3 \ldots 10 \%$.

Thus, at this stage, a comprehensive study of the influence of external pressure and doping of fast cooling products on the structure and properties of finished compacts.

\section{Research result}

From General considerations, it is clear that an increase in the sintering time leads to an increase in the average diameter of the grains, as well as an increase in their number, and a decrease in the sintering temperature - to a decrease in the grain growth rate and, accordingly, to a decrease in their final size. Reducing the sintering temperature, of course, also helps to reduce the rate of nucleation, and in the amorphous component, respectively, to reduce the number of grains of the phase. When changing three parameters (temperature, pressure and sintering time), it is possible to obtain a structure with the required number of grain embryos per unit volume and their most likely sizes.

Thus, on the basis of model representations it can be concluded that to increase the coercive force it is necessary to reduce the size of the non-magnetic phase $\mathrm{NdCu}_{2}$. To do this, in order to seal the sample, the external pressure was increased to $12 \mathrm{MPa}$, and the sintering temperature was reduced from $1323 \mathrm{~K}$ [33] to $1013 \mathrm{~K}$, in the region of existence of fusible triple eutectic and the sintering time was extended to 1.5 hours. [34]. In order to obtain a higher concentration of particles of the crushed phase $\mathrm{NdCu}_{2}$. The structures of the compacts obtained in this way are given in Fig. 4. This figure shows that the structure of this compact is much denser and more perfect than the structure of the compact of the same composition, which was baked at $9.5 \mathrm{MPa}$ [33].


Fig. 4. The structure and microstructure of the compacts composition $\mathrm{Nd}_{15,2} \mathrm{Fe}_{75,5-\mathrm{x}} \mathrm{C}_{\mathrm{x}} \mathrm{B}_{6,5} \mathrm{Cu}_{1,5} \mathrm{Ti}_{1,3}$ at different magnifications: $a$ $-0,33 \%$ stock. $\mathrm{C} ; b-0.51$ per cent at. C; $c-0.59 \%$ ad. $\mathrm{C} ; d-0.86 \%$ ad. $\mathrm{C}$ 
Microstructure, chemical composition and distribution of elements on the surface of the compact composition $\mathrm{Nd}_{15,2} \mathrm{Fe}_{74,991} \mathrm{~B}_{6,6} \mathrm{C}_{0,51} \mathrm{Cu}_{1,57} \mathrm{Ti}_{1,38}$, which was sintered at a temperature of $\mathrm{T}=1013 \mathrm{~K}$ for 1.5 hours., shown in Fig.5. From Fig. 5 and table. 3 it can be seen that there is a phase in the sample $\mathrm{NdCu}_{2}$ (white areas), as well as etching pits indicate a high concentration of crystal defects in the sample.

The paper presents a statistical analysis with the construction of the particle size distribution $\mathrm{NdCu}_{2}$ in baked compacts. From Fig. 6 it is seen that the particle size of the

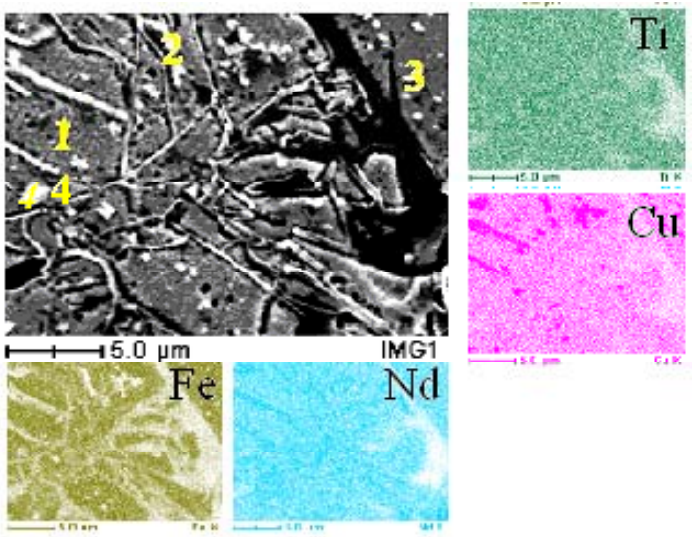

Fig. 5. The microstructure of a compact composition $\mathrm{Nd}_{15,2} \mathrm{Fe}_{74,991} \mathrm{~B}_{6,6} \mathrm{C}_{0,51} \mathrm{Cu}_{1,57} \mathrm{Ti}_{1,38}$

Table 3 - Local chemical analysis of the compact $\mathrm{Nd}_{15,2} \mathrm{Fe}_{74,991} \mathrm{~B}_{6,6} \mathrm{C}_{0,51} \mathrm{Cu}_{1,57} \mathrm{Ti}_{1,38}$

\begin{tabular}{|c|c|c|c|c|c|c|}
\hline \multirow{2}{*}{$№$ poit } & \multicolumn{5}{|c|}{ Content of elements, at\% } & \multirow{2}{*}{ Phase } \\
\cline { 2 - 6 } & $\mathrm{Ti}$ & $\mathrm{Fe}$ & $\mathrm{Cu}$ & $\mathrm{Nd}$ & $\mathrm{C}$ & \\
\hline 1 & 1,5 & 79,25 & 3,5 & 11,55 & 4,2 & $\mathrm{Nd}_{2} \mathrm{Fe}_{14} \mathrm{~B}$ \\
\hline 2 & 3,5 & 1,6 & 55,7 & 32,8 & 6,4 & $\mathrm{NdCu}_{2}$ \\
\hline 3 & 2,8 & 5,2 & 57,3 & 31,4 & 3,3 & $\mathrm{NdCu}_{2}$ \\
\hline 4 & 5,7 & 3,4 & 54 & 30,7 & 6,2 & $\mathrm{NdCu}_{2}$ \\
\hline
\end{tabular}

phase $\mathrm{NdCu}_{2}$, which are present in the baked sample obtained under the above conditions, decreased to $0.1 \mu \mathrm{m}$ compared to an average size of $0.35 \mu \mathrm{m}$ for previous sintering conditions [33]. If the size distribution of grains is subject to the Gauss law, we should expect that in the sample there are particles phase $\mathrm{NdCu}_{2}$ (spherical) much smaller size $(<0.05 \mu \mathrm{m}$, Fig. 6$)$. The presence of such particles should lead to a significant increase in the coercive force. As shown in [34], the probability of the existence of phase particles $\mathrm{NdCu}_{2}$ with dimensions less than $0.05 \mu \mathrm{m}$ is extremely high, it is safe to say that the pinning effect makes a major contribution to the mechanism of increasing the coercive force. In table. 4 shows the comparison of the rate of nucleation and growth of particles $\mathrm{NdCu}_{2}$.

It is seen that the average diameter for the inclusions is almost the same (within the error), the embryo formation rate falls by almost 5 times, and the particle growth rate falls by almost 3 times with a decrease in the sintering temperature. This explains the difference in the maximum number of phase particles $\mathrm{NdCu}_{2}$ in the volume of the compact and the existence of two peaks that are offset relative to each other: for the initial pressure of $9.5 \mathrm{MPa}-$ $400 \mathrm{~nm}$ and $1000 \mathrm{~nm}$, and for the initial pressure of $12 \mathrm{MPa}-$ $200 \mathrm{~nm}$ and $600 \mathrm{~nm}$.

Earlier in $[35,36]$ the magnetic properties of individual scales were studied $\mathrm{Nd}_{15,2} \mathrm{Fe}_{75,5-\mathrm{x}} \mathrm{C}_{\mathrm{x}} \mathrm{B}_{6,6} \mathrm{Cu}_{1,57} \mathrm{Ti}_{1,38}$ ( $\mathrm{x} 0,17 \ldots 0.86 \% \mathrm{ad})$, hardened from a liquid state, as well as magnetic plastics, which are made of flakes after annealing from alloys of the same composition. It should be noted that the magnetic plastics made from flakes, which are obtained after quenching and annealing at a temperature of $773 \ldots 873 \mathrm{~K}$, have a significant coercive force, about 1450 $\mathrm{kA} / \mathrm{m}$, and, at the same time, a slight residual induction of $0.5 \ldots 0.6 \mathrm{~T}[36]$.

For rice. 7 hysteresis loops are presented for compacts that are sintered at an initial pressure of $12 \mathrm{MPa}$ and a temperature of $1023 \mathrm{~K}$. it is Seen that they differ significantly from hysteresis loops for compacts that are sintered at a temperature of $1323 \mathrm{~K}$, namely: the loop approaches a rectangular one. At the same time, there is an area with "constriction".

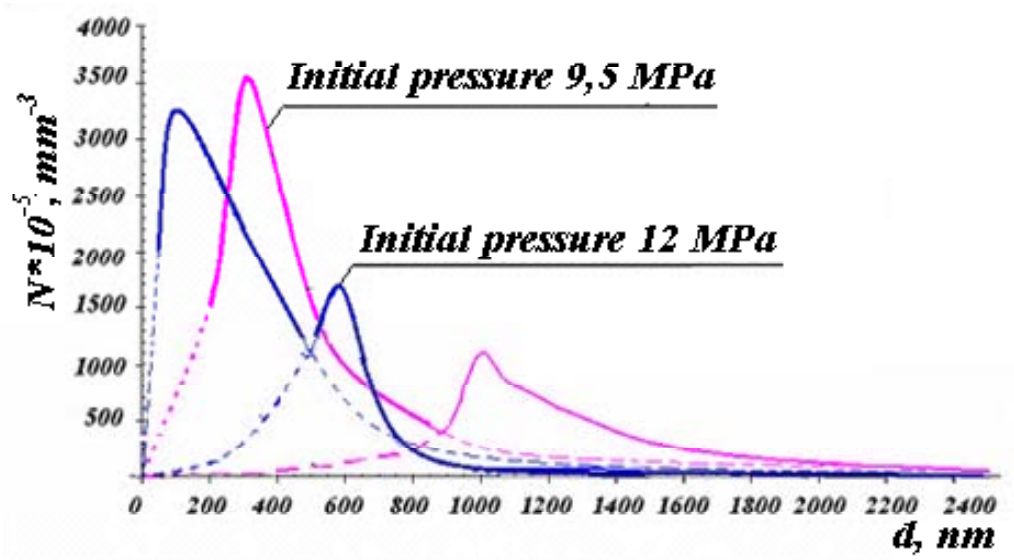

Fig. 6. Diagram of distribution of particles $\mathrm{NdCu}_{2}$ the size of the compact composition $\mathrm{Nd}_{15,2} \mathrm{Fe}_{74,99} \mathrm{C}_{0,51} \mathrm{~B}_{6,6} \mathrm{Cu}_{1,57} \mathrm{Ti}_{1,38}$ 

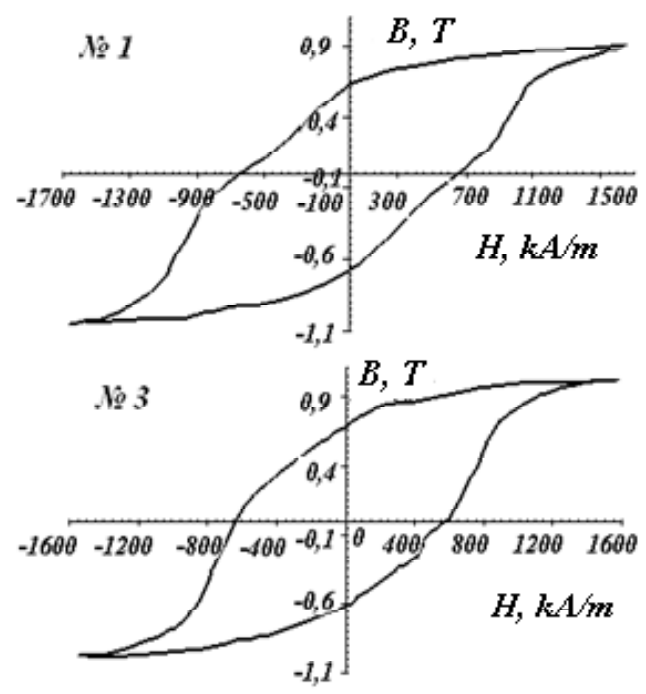

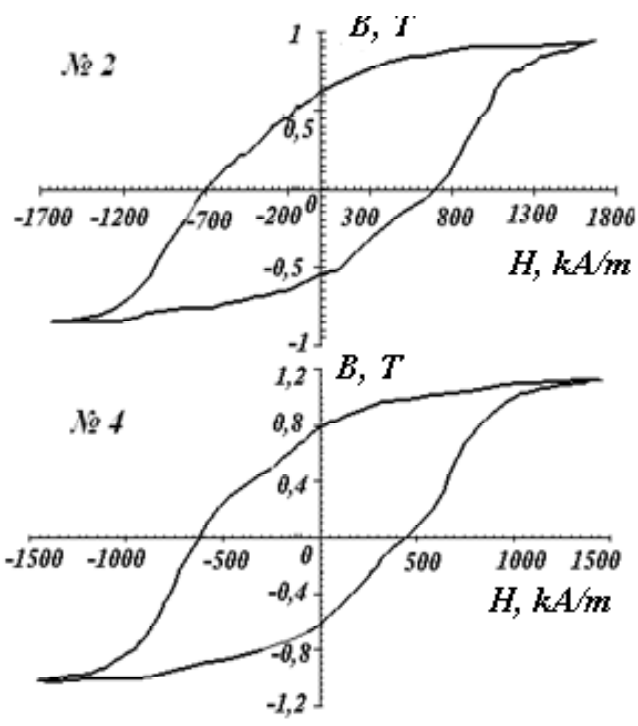

Fig. 7. Hinges of hysteresis of compacts of $\mathrm{Nd}_{15,2} \mathrm{Fe}_{75,5-\mathrm{x}} \mathrm{C}_{\mathrm{x}} \mathrm{B}_{6,6} \mathrm{Cu}_{1,57} \mathrm{Ti}_{1,38}$ alloy, which were sintered at an initial pressure of $12 \mathrm{MPa}$ and temperature 1023 K: № $1-0,51 \%$ at. C; № $2-0,33 \%$ at. C; № $3-0,59 \%$ at. C; № $4-0,86 \%$ at. C.

To determine the actual value of the magnetic energy of the magnets prepared from the sintered compacts made from alloys bonded $\mathrm{Nd}_{15,2} \mathrm{Fe}_{75,5-\mathrm{x}} \mathrm{C}_{\mathrm{x}} \mathrm{B}_{6,6} \mathrm{Cu}_{1,57} \mathrm{Ti}_{1,38},(\mathrm{x}$ : $0.33 \ldots 0.86 \%$ of JSC). For this purpose, the baked compacts were crushed in a ball mill and magnetic plastics were made from powders using traditional technology. Microstructure of bonded, which are thus obtained, served on rice. 8 .

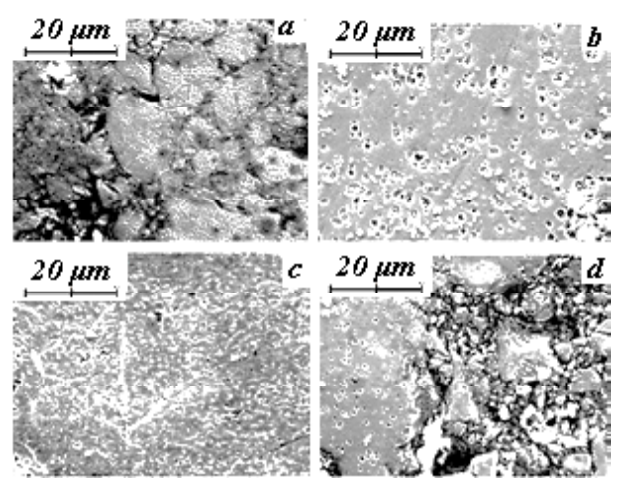

Fig. 8. Microstructure magnetoplasma that was made of sintered at a temperature of $1013 \mathrm{~K}$ and at an initial pressure of $12 \mathrm{MPa}$ compact composition

$\mathrm{Nd}_{15,2} \mathrm{Fe}_{75,5-\mathrm{x}} \mathrm{C}_{\mathrm{x}} \mathrm{B}_{6,6} \mathrm{Cu}_{1,57} \mathrm{Ti}_{1,38}: a-0.33 \%$ at. $\mathrm{C} ; b-0.51$ per cent at. $\mathrm{C} ; c-0.59 \%$ at. $\mathrm{C} ; d-0.86 \%$ at. $\mathrm{C}$

The determination of the magnetic properties of the obtained bonded was carried out on demagnetization curves (Fig. 9). As can be seen from this figure, the coercive force of magnitoplasts, which are made of compacts that are sintered at a sintering temperature $(\mathrm{T}=1013 \mathrm{~K})$ and initial pressure $(\mathrm{P}=12 \mathrm{MPa})$, has increased sharply compared to the previous sintering regime [33], and reached values of $900 \ldots 1350 \mathrm{kA} / \mathrm{m}$ with a residual magnetic field of $0.6 \ldots 0.8 \mathrm{TL}$.

For rice. 10 the dependence of the coercive force of $\mathrm{HC}$ on the carbon concentration in the initial alloy is presented. Based on the previous results, a number of experiments to determine the effect of carbon concentration in the alloy were performed $\mathrm{Nd}_{15,2} \mathrm{Fe}_{75,5-\mathrm{x}} \mathrm{C}_{\mathrm{x}} \mathrm{B}_{6,6} \mathrm{Cu}_{1,57} \mathrm{Ti}_{1,38}$ on the magnetic properties of compacts obtained under external pressure. In addition to the results obtained in this paper in Fig. 10 summary data of previous works are given [35,3739]. From them it can be seen that the maximum coercive force falls on the composition of $0.2 \ldots 0.5 \%$ at. carbon's.

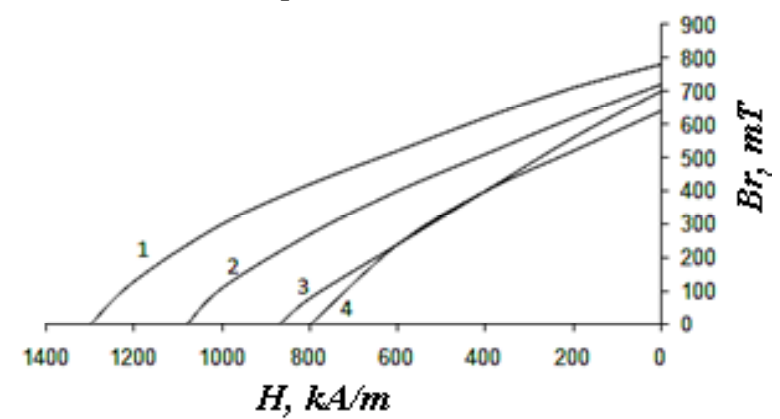

Fig. 9. The demagnetizing part of the magnetic hysteresis loops: № $1-0.51 \%$ at. C; № $2-0.33 \%$ at. C; № $3-0,59 \%$ at. C; № $4-0.86 \%$ at. C

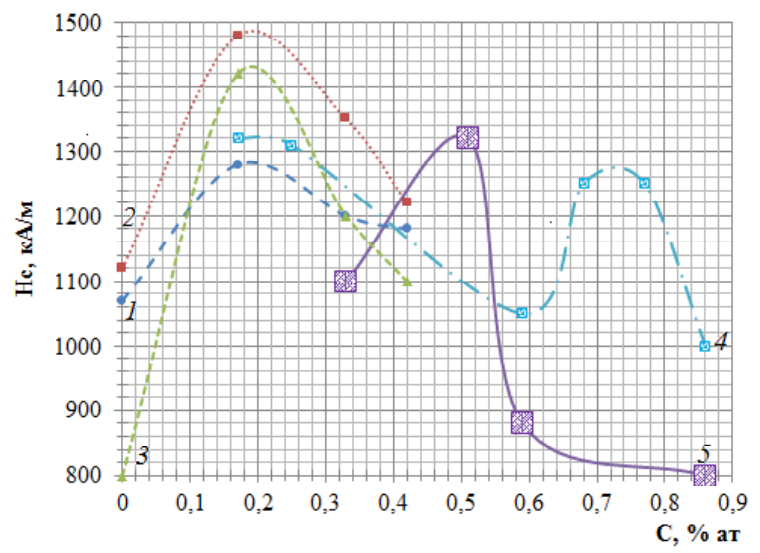

Fig. 10. Dependence of the coercive force value $\mathrm{H}_{C}$ carbon for the sintered compacts and the bonded composition

$\mathrm{Nd}_{15,2} \mathrm{Fe}_{75,5-\mathrm{x}} \mathrm{C}_{\mathrm{x}} \mathrm{B}_{6,6} \mathrm{Cu}_{1,57} \mathrm{Ti}_{1,38:} 1$ - anisotropic magnets to IT; 2 - anisotropic magnets after IT; 3 - after IT is bonded; 4 - bonded without those; 5 - bonded sintered under $12 \mathrm{MPa}$ compacts 


\section{Discussion of results}

The analysis of experimental data allows us to state that the rapid cooling of the alloy $\mathrm{Nd}_{15,2} \mathrm{Fe}_{75,5}$ ${ }_{x} \mathrm{C}_{x} \mathrm{~B}_{6,6} \mathrm{Cu}_{1,57} \mathrm{Ti}_{1,38}$ in hardening products (scales) amorphous and crystalline phases are formed. It is established that the main crystalline phases are $\mathrm{Nd}_{2} \mathrm{Fe}_{14} \mathrm{~B}$, $\mathrm{Nd}_{1.1} \mathrm{Fe}_{4} \mathrm{~B}_{4}$, clean $\mathrm{Nd}$ phase, which is identified as intermetallic $\mathrm{NdCu}_{2}$.

It is known that $\mathrm{Nd}_{2} \mathrm{Fe}_{14} \mathrm{~B}$ formed in the system $\mathrm{Nd}-\mathrm{Fe}$ $\mathrm{B}$ at protectionhow reaction. In the case of rapid cooling from the liquid phase $\mathrm{Nd}_{2} \mathrm{Fe}_{14} \mathrm{~B}$ crystallizes directly from the liquid, bypassing the equilibrium transformation. In addition to phase $\mathrm{Nd}_{2} \mathrm{Fe}_{14} \mathrm{~B}$ in this alloy, a phase of the type $\mathrm{NdCu}_{2}$, which exists in the $\mathrm{Nd}-\mathrm{Cu}$ system with an atomic composition of $\mathrm{Cu}+33 \mathrm{AO} . \% \mathrm{Nd}$ [40], but the copper content in the alloy under study does not exceed $1.6 \%$ AO. and so phase $\mathrm{NdCu}_{2}$, according to the equilibrium state diagram, can not be formed in this alloy. It is known that in the $\mathrm{Fe}-\mathrm{Cu}$ system under certain conditions (the presence of carbon more than 0.3 at.\%), a complete stratification in the fluid may occur [41]. Therefore, the probability of formation of micro domains, which are enriched in copper in the liquid alloy, a large because carbon stabilizes the region of nesmeshivaemost of copper with the main alloy element, iron. So, at highspeed cooling of the alloy from the liquid state intermetallic compounds $\mathrm{NdCu}_{2}$ it can be obtained as a metastable phase based on micro-groups enriched with copper and other elements. According to Miroshnichenko I. S. [42], phases $\mathrm{Nd}_{2} \mathrm{Fe}_{14} \mathrm{~B}, \mathrm{NdCu}_{2}$ it can be called phases with limited metastability.

Previously [33] derived the scales of the composition $\mathrm{Nd}_{15,2} \mathrm{Fe}_{75,5-\mathrm{x}} \mathrm{C}_{\mathrm{x}} \mathrm{B}_{6,6} \mathrm{Cu}_{1,57} \mathrm{Ti}_{1,38}$ placed in the mold and pressed using a mechanical press, then spcala in a vacuum oven at a temperature of $1323 \mathrm{~K}$. the sintering Temperature was chosen according to the technological process of production of anisotropic permanent magnets. As mentioned earlier, the material of the clamp and mounting bolts was selected so that an additional "thermal" pressure of up to $1 \mathrm{HPa}$ could be obtained. Under high pressure conditions, stresses occur that accelerate diffusion processes in the sample $[43,44]$. Thus, on the one hand, the volume growth of phases is carried out $\mathrm{Nd}_{2} \mathrm{Fe}_{14} \mathrm{~B}$ i $\mathrm{NdCu}_{2}$ and at the same time, their stability will be stable, since high pressure displaces the phase equilibrium points in the high temperature region, in accordance with the law of Clapeyron-Clausius.

Since the phase $\mathrm{Nd}_{2} \mathrm{Fe}_{14} \mathrm{~B}$ under these conditions, it does not have time to form into individual grains, and the ndcu 2 phase sizes are such that they do not interfere with the movement of domain boundaries, in this case the value of the coercive force of the sample remains almost constant. In order to avoid the rapid growth of $\mathrm{NdCu} 2$ phase, the initial pressure was increased and the sintering temperature was reduced to the triple fusible eutectic temperature (1013 $\mathrm{K}$ ), and the sintering time was increased to 1.5 hours. These conditions practically did not affect the rate of the phases nucleation $\mathrm{NdCu}_{2}$ and $\mathrm{Nd}_{2} \mathrm{Fe}_{14} \mathrm{~B}$ and at the same time reduced the rate of growth of these phases. As can be seen from figure 4.6 , the phase size $\mathrm{NdCu}_{2}$ it decreased to $0.2 \mu \mathrm{m}$, and in some cases to $0.05 \mu \mathrm{m}$, and the coercive force of the compacts increased by an order of magnitude from $160 \mathrm{kA} / \mathrm{m}$ to $1300 \mathrm{kA} / \mathrm{m}$. Along with this, the amorphous component of the films crystallizes stable and metastable phases under high pressure. The amorphous component is an unordered structure with the absence of a long-range order and therefore, under these conditions, the density of imperfections tends to the maximum, and the processes of transfer of alloying elements, namely, carbon, copper and titanium, to the zone of imperfections (Suzuki-kotrell Cloud, dislocation nuclei, etc.) are accelerated. Reaching critical dimensions, clusters of imperfections enriched with alloying elements also become an obstacle to the displacement of domain boundaries.

Thus, carbon affects the properties of alloys in two ways $\mathrm{Nd}_{15,2} \mathrm{Fe}_{75,5-\mathrm{x}} \mathrm{C}_{\mathrm{x}} \mathrm{B}_{6,6} \mathrm{Cu}_{1,57} \mathrm{Ti}_{1,38},(\mathrm{x}: 0.33 \ldots 0.86 \%$ of the stock.): on the one hand, in the presence of carbon $(0.33 \ldots 0.86$ at. \%) in a liquid alloy, micro-areas are formed, which are enriched with copper, on the basis of which crystals are formed from a liquid state during quenching $\mathrm{NdCu}_{2}$. On the other hand, during crystallization of the amorphous component in alloys $\mathrm{Nd}_{15,2} \mathrm{Fe}_{75,5}$. ${ }_{x} \mathrm{C}_{\mathrm{x}} \mathrm{B}_{6,6} \mathrm{Cu}_{1,57} \mathrm{Ti}_{1,38}$ under high pressure conditions, imperfections are formed in which the alloying elements carbon, copper, titanium, neodymium-are diffused. Micro areas, reaching critical sizes, become an obstacle to the displacement of domain boundaries. And in the first, and in the second cases actively manifests itself pinning-effect.

Complex alloying with carbon, titanium and copper of the alloy "Neomax" was used to increase the magnetic anisotropy of the phase $\mathrm{Nd}_{2} \mathrm{Fe}_{14} \mathrm{~B}$, the dispersion of the primary crystals (modifications of titanium) and the formation of a paramagnetic phase $\mathrm{NdCu}_{2}$, that allows you to use the pinning effect.

\section{Summary}

1. We obtain the cheap cost material exceeding the magnetic characteristics in comparison with the known magnetic systems.

2. Fast cooling of alloys $\mathrm{Nd}_{15,2} \mathrm{Fe}_{75,5-\mathrm{x}} \mathrm{C}_{\mathrm{x}} \mathrm{B}_{6,6} \mathrm{Cu}_{1,57} \mathrm{Ti}_{1,38}$ leads to the formation of metastable phases $\mathrm{Nd}_{2} \mathrm{Fe}_{14} \mathrm{~B}$ and $\mathrm{NdCu}_{2}$, bypassing the equilibrium of the reaction.

3 . With a decrease in the sintering temperature from $1323 \mathrm{~K}$ to $1013 \mathrm{~K}$ under high external pressure, the growth process of metastable phases slows down, which makes it possible to obtain nanoscale phase formations in a compact $\mathrm{NdCu}_{2}$, which prevent the movement of domain boundaries. This increases the value of the coercive force by an order of magnitude $\left(\mathrm{H}_{\mathrm{C}}=1350 \mathrm{kA} / \mathrm{m}\right)$, and the residual induction of almost 2 times $(\mathrm{Br}=0.8 \mathrm{~T})$.

4. It is shown that for non-magnetic inclusions of the $\mathrm{NdCu} 2$ phase up to $50 \mathrm{~nm}$ in size it is possible to obtain the value of the coercive force $6 \ldots 8 \mathrm{MA} / \mathrm{m}$. For the size values 
of non-magnetic inclusions 1 ...The value of the coercive force of $100-200 \mathrm{kA} / \mathrm{m}$ was obtained at $10 \mu \mathrm{m}$, which coincides with the experimental data.

5. Under high external pressure, the maximum coercive force falls on the composition of alloys with carbon in the amount of $0.33 \ldots 0.51$ at. $\%$, due to the maximum diffusion of $\mathrm{C}, \mathrm{Cu}$, Those in the field of imperfections of the structure and interference with the movement of domain boundaries.

\section{References}

1. The dependence of coercivity on anisotropy field in sintered R-Fe-B permanent magnets [Text] /S. Hirosawa, K. Tokuhara, Y. Matsuura [and other] // Journal of Magnetism and Magnetic Materials. - 1986. - Vol. 61. - P. 363-369.

2. Pr-Fe and Nd-Fe-based materials: a new class of high performance permanent magnets [Text] / J.J. Croat, J.F. Herbst, R.W. Lee [and other] // Journal of Applied Physics. - 1984. - Vol. 55. - P. 2078-2082.

3. New material for permanent magnets on a base of $\mathrm{Nd}$ and $\mathrm{Fe}$ [Text] / M. Sagawa, S. Fujimura, N. Togawa [and other] // Journal of Applied Physics. - 1984. - Vol. 55. - P. 20831087.

4. Buschow K.H.J. New developments in hard magnetic materials [Text] / K.H.J. Buschow // Reports on Progress in Physics. - 1991. - Vol. 54. - P. 1123-213.

5. Luo Y. Temperature variation of domain structure and magnetization in Nd-Fe-B magnets [Text] / Y. Luo, N. Zhang // Journal of Applied Physics. - 1987. - Vol. 62. - № 8. - P. 3445-3447.

6. Savchenko A.G., Menushenkov V.P., 2003. Rare-earth permanent magnets: basic principles of development and production technology (Redkozemelnyie postoyannyie magnityi: printsipialnyie osnovyi razrabotki i tehnologiya proizvodstva), "Materials science and metallurgy. Advanced technologies and equipment", Russian-Japanese seminar: Materials of the Russian-Japanese seminar, $125 \mathrm{p}$. (Russian).

7. Relationships between crystal structure and magnetic properties in $\mathrm{Nd}_{2} \mathrm{Fe}_{14} \mathrm{~B}$ [Text] / J.F. Herbst, J.J. Croat, F.E. Pinkerton [and other] // Phys.Rev. - 1984. - B29. - 4176 p.

8. Suzuki T. Lorentz microscopy observation of domain walls in Nd-Fe-B alloy permanent magnets [Text] / T. Suzuki, K. Hiraga, M. Sagawa // Jap. J. Of Appl. Phys. - 1984. - P. L421-423.

9. Durst R.D., Kronmuller H. Magnetic hardening mechanism in sintered $\mathrm{Nd}-\mathrm{Fe}-\mathrm{B}$ and $\mathrm{Sm}-\mathrm{Co}-\mathrm{Cu}-\mathrm{Fe}-\mathrm{Zr}$ permanent magnets [Text] / R. D. Durst, H. Kronmuller // Proc. $8^{\text {th }}$ Int. Workshop on RE magnets.- Dayton. - 1985. - P. 725-734.

10. Permanent magnets of REM-Fe-B Alloys with low temperature coefficient of residual induction [Text] / A.V. Andreev, A.V. Deryagin, V. N. Moskalev [et al.] / / 8th allUnion conference on permanent magnets : theses. Novocherkassk. - 1985. - P. 18-19.

11. The hysteresis properties and magnetization reversal mechanism of the alloys

12. Nd-Fe-B [Text] / A. S. Lileev, S. A. Melnikov, V. P. Menushenkov [et al.] / / Metally. - 1988. - №5. - P. 165168.

13. Study of the processes of magnetization reversal of permanent magnets based on neodymium, iron and boron alloys [Text] / D. D. Mishin, S. M. Egorov, E. B. Shamorikova // Physics of magnetic materials. - Kalinin,
1988. - C. 18-39.

14. Temperature dependence of the coercivity and the anysotropy of $\mathrm{Nd}-\mathrm{Fe}-\mathrm{B}$ based magnets [Text] / R. Grossinger, R. Krewenka, F. Hoslinger [and other] // IEEE Trans. Magn. - 1987. - Vol. MAG-23, № 5. - P. 2114 2116.

15. Hirosawa S. Magnetizing process in R-Fe-B sintered permanent magnets studied on boron-rich $\mathrm{R}_{17} \mathrm{Fe}_{83-\mathrm{x}} \mathrm{B}_{\mathrm{x}}$ magnets $(\mathrm{R}=\mathrm{Pr}, \mathrm{Nd})$ [Text] / S. Hirosawa, M.Sagawa // Journal of Magnetism and Magnetic Materials. - 1987. Vol.71. - P. L1-L6.

16. Durst K. D. The coercive field of sintered and melt-spun NdFeB magnets [Text] / K.D. Durst, H. Kronmuller // Journal of Magnetism and Magnetic Materials. - 1987. - Vol. 68. P. 63-75.

17. Kronmuller $\mathrm{H}$. Angular dependence of the coercive field in sintered $\mathrm{Fe}_{77} \mathrm{Nd}_{15} \mathrm{~B}_{8}$ magnets [Text] / H. Kronmuller, R.D. Durst, H. Maptinek // Journal of Magnetism and Magnetic Materials. - 1987. - Vol. 69. - P. 149-157.

18. Kronmuller $\mathrm{H}$. Teory of nucleation fields in inhoriogeneous ferromagnets [Text] / H. Kronmuller // Phys. Stat. Sol. 1987. - Vol. 144. № 6. - P. 385 -396.

19. Strnat K.J. High and low temperature property of sintered Nd-Fe-B magnets [Text] / K.J. Strnat, D. Li, H.F. Mildrum // Proc. $8^{\text {th }}$ Int. Workshop on RE magnets. - Dayton. 1985. - P. 575-586.

20. Hojipanayis G.C. Temperature dependence of magnetic hysteresis in meltspun and sintered Nd-Fe-B magnets / G.C. Hojipanayis, A. Kim // IEEE Trans. Magn. - 1987. Vol. MAG-23, №5. - P. 2533-2535.

21. Relationships between crystal structure and magnetic properties in $\mathrm{Nd}_{2} \mathrm{Fe}_{14} \mathrm{~B}$ [Text] / J.F. Herbst, J.J. Croat, F.E. Pinkerton [and other] // Phys. Rev. B. - 1984. - Vol. 29. 4176 p.

22. Савченко А.Г. Эффект Мессбауэра на ядрах ${ }^{57} \mathrm{Fe}$ в сплавах для постоянных магнитов на основе $\mathrm{Nd}-(\mathrm{Fe}, \mathrm{Co}, \mathrm{M})$ В, где М - Al или Ті [Текст] / А. Г. Савченко, В. П. Менушенков, А.С. Лилеев // Металлы. - 1996. - № 1. $108 \mathrm{c}$.

23. Herbst J.F. $\mathrm{R}_{2} \mathrm{Fe}_{14} \mathrm{~B}$ materials: Intrinsic properties and technological aspects [Text] / J.F. Herbst // Rev. Mod. Phys. - 1991. - Vol. 63. - 819 p.

24. Mottram R.S. Blending additions of cobalt to $\mathrm{Nd}_{16} \mathrm{Fe}_{76} \mathrm{~B}_{8}$ milled powder to produce sintered magnets [Text] / R.S. Mottram, A.J. Williams, I.R. Harris // J. Magn. and Magn. Mater. - 2000. - Vol. 217. - 27 p.

25. Structure, magnetic properties and corrosion behaviour of sintered $\mathrm{Nd}_{16} \mathrm{Fe}_{76-\mathrm{x}} \mathrm{Cr}_{\mathrm{x}} \mathrm{B}_{8}$ magnets [Text] /S. Szymura, H. Bala, G. Pawlowska [and other] // J. Less-Common Met. 1991. - Vol. 175. - 185 p.

26. Zhuravlev A. A. Magnetic properties and parameters of mussbauer spectra of RfeBM magnets [Text] / A. Zhuravlev, S. M. Margaryan, A. A. Lukin // XII international conference on permanent magnets: abstracts, (Suzdal, Russia, September 22-26, 1997). - Suzdal, $1997-60$ p.

27. Tatam C. Rare earth magnet s: raw materials issues [Text]/ C.Tatam, I.Higgins, D.Kennedy // Proc. of the 18 th Int. Workshop on HPMA. Annecy. - 2004.- P. 15-22.

28. Kekalo I. B. Physical metallurgy of precision alloys. Alloys with special magnetic properties [Text]/ I. B. Kekalo, B. A. Samarin. - Moscow : Metallurgy, 1991. - 480 p.

29. Vonsovsky S. V. Magnetism [Text]/S. V. Vonsovsky. Moscow : Science, 1971. - $1032 \mathrm{p}$. 
30. Krinchik, G. S. Physics of magnetic phenomena [Text] / G. S. Krinchik. - M. : Izd-vo Mosk. UN-TA, 1976. - 262 p.

31. Kondorsky E. I. Zone theory of magnetism [Text] / E. I. Kondorsky. - M: MOSCOW STATE UNIVERSITY, 1976. $-217 \mathrm{p}$.

32. The influence of external pressures on the structure and magnetic properties of sintered magnets / G. P. Brekharya, T. V. Gulyaeva, A. A. Kharitonova, T. I. Device // New materials and technologies in metallurgy and mechanical engineering. - Zaporozhye: ZNTU. -2013.- № 2. - P. 2329.

33. Brekharya G. P. Properties of the permanent magnets Nd$\mathrm{Fe}-\mathrm{B}$ alloy with $\mathrm{Cu}, \mathrm{Ti}, \mathrm{C}$, obtained by a powder method or sintering of films in high-pressure conditions [Text] / G. P. Brekharya, E. A. Kharitonova, T. V. Gulyaeva // Progress in physics of metals. - K. : IMF. - vol. 15. - 2014, p. 35 53.

34. Gulyaeva T.V. On the study of the influence of external pressure and carbon on structure and properties of compacts made on the basis of rapidly cooled alloys of Nd-Fe-(B,C)$\mathrm{Cu}-\mathrm{Ti} / \mathrm{T} . \mathrm{V}$. Gulyaeva // Innovative materials and technologies in metallurgy and mechanical engineering. 2018. - № 1. - P. 33-40.

35. Behara G. P. the Influence of compressive stresses, which are applied in the sintering process of amorphous flakes of a composition $\mathrm{Nd} 33 \mathrm{Fe} 63,34 \mathrm{~B} 1,1 \mathrm{Cu} 1,5 \mathrm{Ti1}, 0 \mathrm{C} 0,06$, on the structure and magnetic properties of compacts / G. P. Brekharya, T. V. Gulyaeva, T. V. Kalnysh // Bulletin of Dnipropetrovsk University, Series: Physics. Radio electronics,- Dnepropetrovsk: DNU. - 2010. - Issue. 17. Vol. 18. - № 2. - P. 92-97.

36. Thermocycle processing of alloys of rare - earth $\mathrm{Fe}-\mathrm{B}$ in the temperature region of spin-orientation phase transition / G. P. Brekharya, S. V., Domashenko, V. Nemoshkalenko [et al.] / / metallophysics and newest technologies. - 2001 . -23 , № 12. - P. 1687-1695.

37. Research into the influence of copper, carbon and titanium on the properties of permanent magnets based on $\mathrm{Fe}_{76} \mathrm{Nd}_{16} \mathrm{~B}_{8}$ alloy / G. Brekharya, E. Kharitonova, A. Bovda [and other] //Proceedings of the $21^{\text {st }}$ of the Workshop on Rare-Earth permanent magnets and their application. - Bled, Slovenia, 2010. - P. 236-239.

38. Behara G. P. the Effect of copper on the properties of permanent magnets made of alloy Fe76Nd16B8 / Bracharia G. P., E. A. Kharitonov // metallophysics and newest technologies. - 2013. - 35, № 3. - P. 367-375.

39. Pat. 105308 Ukraine, IPC H01F 1/057 H01F 1/053 B22F $3 / 12$. The material for rare earth permanent magnet and method of its obtaining / Bracharia G. P., Kharitonov A. A., dektaryenko V. A. [and others], the owner of Kyiv, Institute of metal physics to them. G. V. Kurdyumov of NAS of Ukraine. - no. a 201302023, applications. 19.02.2013, publ. 25.04.2014, Byul. No. 8.

40. Pat. utility model 92390 Ukraine, IPC H01F 1/00 H01F 1/ $053 \mathrm{H} 01 \mathrm{~F} 1 / 057$. Amethod of producing permanent magnets based on alloys of Nd-Fe-B / Bracharia G. P., Gulyaeva T. V., Kharitonov A. A. [and others]; applicant and owner of Kyiv, Institute of metal physics to them. G. V. Kurdyumov of NAS of Ukraine. - № u 2014 03132, statements. 28.03.2014, publ. 11.08.2014, Byul. No. 15 .

41. Hansen M. structures of double alloys: reference book : in 2 volumes / M. Hansen, K. Anderko [transl. by P. K. Novick et al.]. - M.: Metallurgizdat, 1962. - 1488 p.: Il.

42. Kronmuller H. Analysis of the magnetic hardening mechanism in RE-FeB permanent magnets / H. Kronmuller, K.D. Durst, M. Sagawa // Journal of Magnetism and Magnetic Materials. - 1988. - Vol. 74. - 291 p.

43. I. S. Miroshnichenko, Quenching from the liquid state/ I. S. Miroshnichenko. - Moscow: Metallurgy, - 1982. - 168 p.

44. Shumon P. Difusion in solids / P. Shumon; [lane. with eng.]. - Moscow: Metallurgy, 1966. - 195 c.

45. Dudorov A. E. Equations of dynamics and kinetics of dislocations at high rates of plastic deformation / A. E. Durov, A. E. Mayer // Bulletin of Chelyabinsk state University, Physics. - 2011. - issue. 12. - № 39 (254). - P. $48-56$.

Одержано 26.06.2019

Гулясва Т. В., Брехаря Г. П. Про дослідження впливу зовнішнього тиску та вуглецю на структуроутворення та властивості компактів, що спечені на основі швидко охолоджених сплавів Nd-Fe-(C,B)-Cu-Ti (Частина 2)

Мета роботи. Комплексне дослідження термодинамічних та фізико-хімічних умов утворення фаз в готових постійних магнітах, щзо виготовляються на основі систем $\mathrm{Fe}-\mathrm{Nd}$-B.

Методи дослідження: металографічний, рентгеноспектральний, магнітометричний.

Отримані результати. Досліджується вилив зовнішнього тискута незначної кількості вуглецю (0,17...0,86\% ат) на структуру та властивості постійних магнітів, які виготовлені на основі системи $\mathrm{Nd}-\mathrm{Fe}-\mathrm{B}$, щзо леговані міддю та титаном. Для виготовлення постійних магнітів з високою магнітною енергією використано продукти швидкого охолодження з рідкого стану. Для изьго лусочки, щзо отримані методом ЗРС, пресували у прес-формі та спікали у вакуумі. Прес-форма та болти, щуо їх скріплюють, виготовлені зі сплавів, у яких різні коефіцієнти лінійного розширення. Цей метод дає змогу досягти високого тиску ( 1 ГПа) під час спікання. Спікання виконували у вакуумі під тиском $P=12$ МПа та при температурі $1013 \mathrm{~K}$.

Показано, щуо вуглець двояко впливає на властивості сплавів $\mathrm{Nd}_{15,2} \mathrm{Fe}_{75,5-x} C_{x} B_{6,6} \mathrm{Cu}_{1,57} \mathrm{Ti}_{1,38}, \quad(x: 0,33 \ldots 0,86 \%$ aт.): з одного боку, в присутності вуглецю (0,33...0,86 ат.\%) в рідкому сплаві, утворюються мікрообласті, які збагачені міддю, на базі яких при загартуванні з рідкого стану зароджуються кристали $N d С$. $_{2} 3$ іншого боку, при кристалізації аморфної складової в сплавах $\mathrm{Nd}_{15,2} \mathrm{Fe}_{75,5-x} \mathrm{C}_{x} B_{6,6} \mathrm{Cu}{ }_{1,57} \mathrm{Ti}_{1,38}$ в умовах високого тиску утворюються області недосконалостей, в які дифундують легувальні елементи - вуглець, мідь, титан, неодим. Мікрообласті, досягаючи критичних розмірів, стають перешкодою зміщення границь доменів. I в першому, $і$ в другому випадках активно проявляється піннінг-ефект. 
Наукова новизна. Встановлено, щуо зниження температури спікання швидко охолоджених лусочок сплавів $\mathrm{Nd}_{15,2} \mathrm{Fe}_{75,5-x} \mathrm{C}_{x} \mathrm{~B}_{6,6} \mathrm{Cu}_{1,57} \mathrm{Ti}_{1,38}$ в умовах високого тиску порядку 0,9 ГПа від технологічної 1323 К до температури

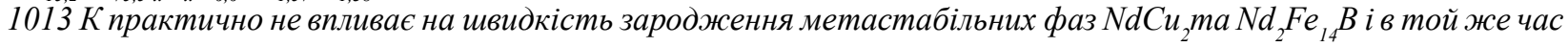
знижує швидкість їх росту. Однак, це призводить до збільшення коерцичтивної сили готових магнітів від 160 $\kappa A / м$ до $1300 \kappa A /$ м.

Практична цінність. Одержані в роботі результати мають важливе значення для подальшого розвитку фізичного матеріалознавства магнітожорстких матеріалів та сучасної техніки.

Ключові слова: спікання, «термічний» тиск, відпал, основна магнітожсорстка фаза, фаза з обмеженою метастабільністю, коеричитивна сила.

Гуляева Т. В., Брехаря Г. П. Об исследовании влияния внешнего давления и углерода на структурообразование и свойства компактов, испеченных на основе быстро охлажденной сплавов Nd-Fe-(C,B)-Cu-Ti (Часть 2)

Цель работы. Комплексное исследование термодинамических и физико-химических условий образования фаз в готовых постоянных магнитах, изготавливаемых на основе систем Fe-Nd-B.

Методы исследования: металлографический, рентгеноспектральный, магнитометрический.

Полученные результаты. Исследуется влияние внешнего давления и незначительного количества углерода $(0,17 \ldots 0,86 \%$ am) на структуру и свойства постоянных магнитов, изготовленных на основе системы $N d-F e-$ $B$, легированных медью и титаном. Для изготовления постоянных магнитов с высокой магнитной энергией использовано продукты быстрого охлаждения из жидкого состояния. Для этого чешуйки, полученные методом ЗЖС, прессовали в пресс-форме и спекали в вакууме. Пресс-форма и болты, которыми скрепляют, изготовленные из сплавов с различными коэффициентами линейного расширения. Этот метод позволяет достичь высокого давления ( $\approx 1$ ГПа) при спекании. Спекание выполняли в вакууме под давлением Р=12 МПа + 0,9 ГПа и при температуре $1013 \mathrm{~K}$.

Показано, что углерод оказывает двоякое влияние на свойства сплавов $\mathrm{Nd}_{15,2} \mathrm{Fe}_{75,5-x} \mathrm{C}_{x} B_{6,6} \mathrm{Cu}_{1,57} T i_{1,38}$, (x: 0,33 ... 0,86\% ат.): С одной стороны, в присутствии углерода $(0,33 \ldots 0,86$ ат. \%) в жидком сплаве, образуются микрообласти, которые обогащены медью, на базе которых при закалке из жидкого состояния зарождаются

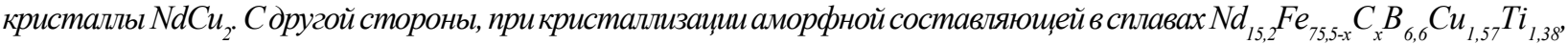
в условиях высокого давления образуются области несовершенств, в которые диффундируют легируюшие элементы - углерод, медь, титан, неодим. Микрообласти, достигая критических размеров, становятся препятствием для смещения границ доменов. И в первом, и во втором случаях активно проявляется пиннингэффект.

Научная новизна. Установлено, что снижение температуры спекания быстро охлажденных чешуек сплавов $\mathrm{Nd}_{15,2} \mathrm{Fe}_{75,5-x} \mathrm{C}_{x} B_{6,6} \mathrm{Cu}_{1,57} \mathrm{Ti}_{1,38}$ в условиях высокого давления порядке 0,9 ГПа от технологической $1323 \mathrm{~K}$ до

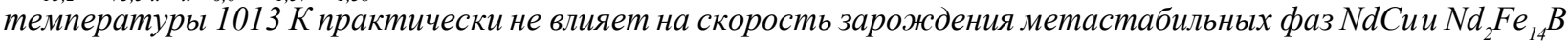
и в то же время снижает скорость их роста. Однако, это приводит к увеличению коэриитивной силы готовых магнитов $160 \kappa \mathrm{\kappa} / \mathrm{м}$ до $1300 \kappa \mathrm{\kappa} / \mathrm{M}$.

Практическая ценность. Полученные в работе результаты имеют важное значение для дальнейшего развития физического материаловедения магнитожестких материалов и современной техники.

Ключевые слова: спекание, «термическое» давление, отжиг, основная магнитожестких фаза, фаза с ограниченной метастабильнистю, коэричитивная сила. 